\title{
断層パラメータの予測誤差を考慮した 広帯域地震動の評価
}

\author{
大塚 久哲 $\cdot$ P. P. G. SOMERVILLE ${ }^{2} \cdot$ 佐藤 俊明 3 \\ リフェロー 工博 九州大学教授 工学部建設都市工学科（T812 福岡市東区箱崎 6-10-1） \\ 2Ph.D Woodward-Clyde Consultants, Senior Associate (566 El Dorado St.,Suite 100,Pasadena,CA91101,USA) \\ ${ }^{3}$ 工博 （株）大崎総合研究所 主席研究員（干100 東京都千代田区内幸町 2-2-2）
}

短周期帯域と長周期帯域とで異なった手法を用いて地震動を作成した後, それらを合成して広帯域地震 動を求める手法（ハイブリッド法）を用いて，1923 年関東地震および相模トラフに㧍ける将来の大地震の 広帯域地震動の推定を行った。この際, 将来発生する地震動に関しては震源パラメータの不確定性を考慮 して，960 波の時刻歴波形を発生させ，それらを統計的に処理して，平滑化応答スペクトルを標淮偏差と ともに提示した. さらにこの平滑化スペクトルを代表する 10 個の時刻歴波形を選定した.

Key Words: strong ground motion time history, variable-slip model, broadband simulation hybrid method, Sagami trough, response spectrum, median and standard deviation

\section{1. 序論}

土木の大規模プロジェクトにおいて構造物, 例え ば吊橋のような長大橋梁の耐震設計を行う場合, 当 該地点の地震動を的確に評価することが重要である. これまでの大規模プロジェクトにおいては, 過去に 発生した大地震を参考にして, 当該地点に影響を及 ぼすと考えられる大地震の規模と震央距離とから距 離減衰式を使って当該地点の地震動を評価する手法 が用いられてきた。しかしながら,プレート境界に 近い地理的状況と, 狭险な国土に活断層が 2000 本以 上存在するといわれているわが国において, 今後, 大規模プロジェクトを企画した場合, 断層近傍に長 大橋梁等を建設することが避け難いと思われ，この ような場合, 地震動の距離減衰式を用いる方法では, 当該地域の断層の特性と, 建設地点と断首との位置 関係などを考虑した精度の高い地震動の評価は困難 であろう。また, 1995 年兵庫県南部地震によって, 日本においても内陸型活断首による直下型地震を考 虑した構造物の耐震設計の重要性が認識されつつあ る.

このような観点から, 断層モデルによって当該地 点の地震動を予測する手法が開発されつつあるが, わが国においてはこれらの手法が実用的であるかの 検討はほとんどなされていないのが現状である. 現 在, このような手法には, 文献 1)に示されるような 経験的グリーン関数を用いる手法が提唱されている
が，これは当該地点において想定地震のマグニチュ ードより 2 程度小さいマグニチュードをもつ地震動 の記録が得られている必要があり，どこにでも適用 できる一般的な手法とは言い難い。したがって，本 研究では, 当該地点の地震動を評価する手法として, 当該地点における小地震の記録が得られていない場 合にも適用できる手法を用いることとした．

また，吊橋のような長大土木構造物の設計に当た つては短周期帯域と長周期帯域の両方の帯域をもつ 広帯域において地震動を精度よく評価することが求 められる. 本研究では, 短周期帯域と長周期帯域と で異なった手法により地震動を作成した後，それら を合成して広帯域地震動を求める手法（ハイブリッ ド法）を用いて，プレート境界型地震の断層モデル から広帯域地震動の推定を行うこととした。

但し，このようにして得られた地震動は，一組の 震源パラメータを仮定した上での地震動の評価であ って, 将来発生するであろう大地震の震源パラメー 夕を確定論的に予測することは現段階では不可能で あるといわざるを得ない。したがって，想定される 震源パラメータの範囲を地震学的に考慮して種々の パラメー夕を組み合わせて多数の地震動を発生させ, それらを統計的に処理して, 将来発生する地震動の 予測平均值や予測誤差の標準偏差を提示していくこ とが, 必要であると考える. そこで, 震源パラメー 夕を種々変化させたときの地震動を 960 波発生させ, 予想される地震動がどの程度の平均値とばらつきを 
有し, このような考え方が工学的に有用であるかを 1923 年関東地震の断層モデルを用いて考察した。さ らに, 平滑化スペクトルを代表する 10 個の地震波形 を選定した。

\section{2. 広帯域地震動の推定手法}

広帯域の時刻歴波形をシミュレーションするため にハイブリッド法を用いた。この方法は, 地震動を 長周期帯域と短周期帯域に分けて計算した後にその 両者を合成し時刻歷波形を求める方法である

（Somerville et al，1996）. 本研究で用いた長周期及 び短周期帯域それぞれの地震動作成の方法を簡潔に 述べれば以下のとおりである. なお, 本研究での長 周期地震動と短周期地震動の作成には, 境界周期 3 秒の周波数フィルターを用い, 時間領域で合成した.

長周期帯域においては地震波振幅の方位特性, 断 層の破壊伝播効果および媒質の波動伝播効果を理論 的に計算し, 波形を求める方法 (Hartzell and Heaton, 1983）を用いている.この方法は近年起こった多く の地震による長周期強震動の波形のモデル化を行う 際に広く用いられ, 強震記録からインバージョンに よって震源過程を求める際の典型的な一つの方法と なつている.

短周期帯域においては, 既往の大地震の震源近傍 で起こった中小地震の強震観測記録から求めた経験 的震源時間関数と, Helmberger（1974）の一般化波線 理論において, 地震波振幅の方位特性を無視して計 算されたグリーン関数（Somerville et al, 1991）を用 いて, 半経験的に地震動を作成する.

\subsection{3 年関東地震の断層モデルと地震動評価}

\section{（1）震源特性，伝播特性およびサイト特性}

本手法の適用事例として 1923 年関東地震を取り上 げ，同地震による東京湾湾口部のサイトA（図-1） の地震動を推定する. 断層モデルとしては, 測地デ 一夕と遠地実体波を用いたインバージョンによって 求められた Wald and Somerville（1995）のモデルを用 いる.このモデルは小田原付近と三浦半島付近にア スペリティがあるが, 体験談に基づいた武村・池浦 （1994）の推定によれば, 短周期地震波もこれらの アスペリティ付近から強くでているということであ り,このモデルは広帯域地震動の評価にとって適切 であると考えられる．表 1 に断層モデルのパラメー 夕を示す. 図-1 は断層面の地表面への投影面を示し

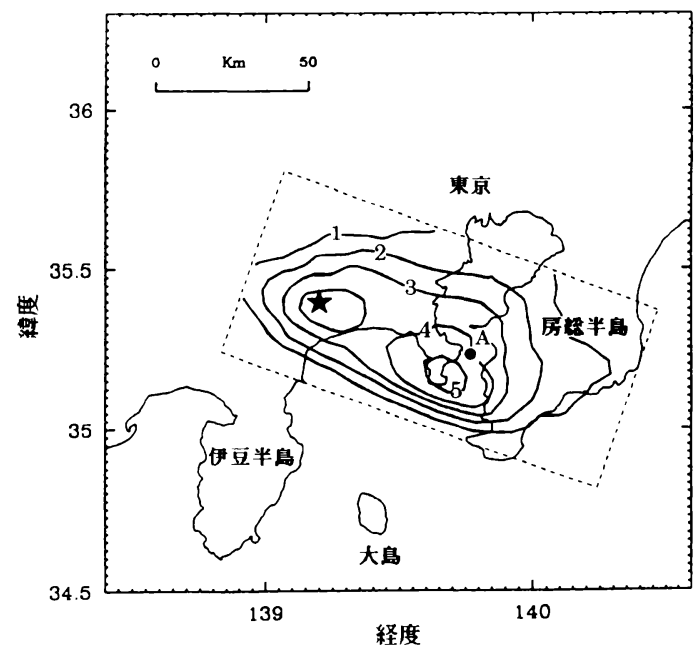

図-11923 年関東地震の断層, 最終滑り量分布（単位 $\mathrm{m}$ ), およびサイトAの位置

表- 1 破壊モデルパラメータ

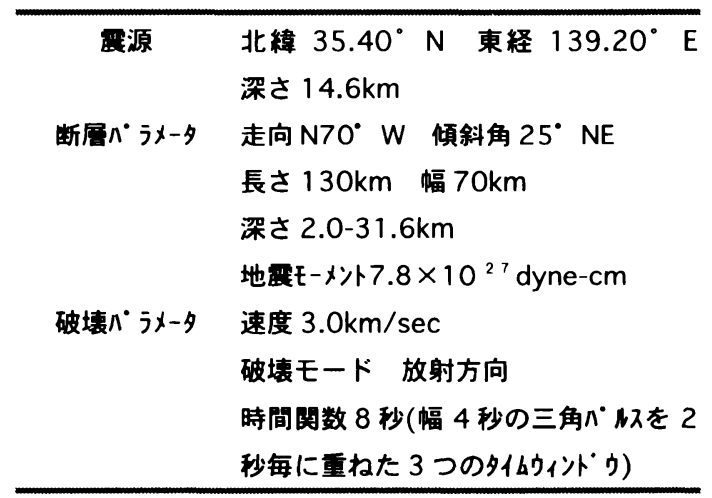

ており, 最終すべり量のコンター図と地震動を求め るサイト A，震央の位置を併せて示している．

断層面は長さ方向に 10 分割, 幅方向に 7 分割され た要素断層によってモデル化した.このモデルでは, 断層上の滑り量と滑りの向きが70個の要素断層に対 して図- 2 のように規定されている.この断層モデル の特徵は滑り量が大きな領域（アスペリティ）が 2 つ存在することにある.

図- 2 は最終滑りの分布のみを示すが, 長周期地震 動の計算においては Wald and Somerville（1995） の インバージョンの過程で求められた時間依存を有す る滑り量と滑りの向きを用いる．具体的には，それ ぞれの要素断層の滑りの時間的変化は, 幅 4 秒の三 角パルス状の遠方場震源時間関数を 2 秒ごとに重ね 


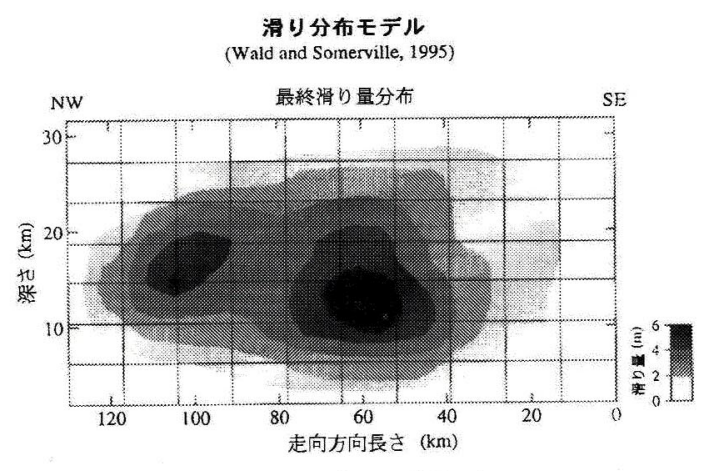

(a) 最終滑り量分布

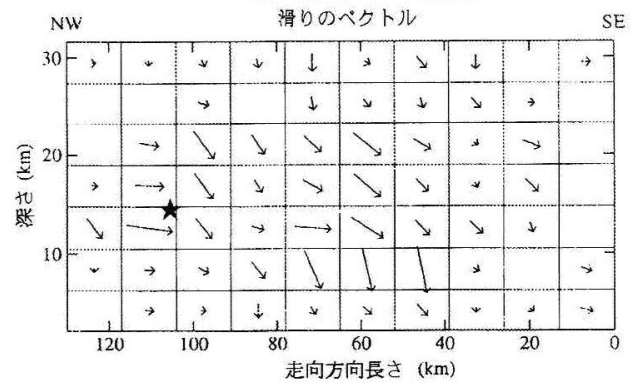

（b）要素断層ごとの滑りの向きと最終滑り量を表す ベクトル

図-21923 年関東地震の不均質滑りを考慮した断層モデル

た 3つのタイムウインドウで表現している：3つの 時間関数が重ね合わせられた状態での震源時間関数 はトータルで 8 秒の時間幅となる. Wald and Somerville (1995)の断層モデルでは，3つのそれぞれ の震源時間関数に対応して, 要素断層上での滑り量, 滑りの方向が規定されている.この断層モデルの妥 当性は国内のいくつかの地点で得られた1923年関東 地震の本震記録のシミュレーションによって検証さ れており, 波形の再現性は良好であることが示され ている（佐藤他, 1996a）. なおこの断層モデルの特 徵と整合する 2 つのアスペリティーを持つ比較的単 純な断層モデルを用いた同様のシミュレーションで も波形の再現性は良好であった（野澤他, 1995）。

さて, 短周期帯域の計算には経験的震源時間関数 が必要である. 1923 年関東地震直後の余震以降, 断 層面近傍では $\mathrm{M} 7$ 程度の地震は発生していない. 東 京本郷で得られた1923年関東地震の余震記録は本検 討で対象とする短周期成分までの分解能はない。し たがって, ここでは, 関東地震と同様にプレ一ト境 界で起こった巨大地震である1985年ミチョアカン地 震（Mw8.0）の際の Mw6.8 の余震による Caleta de Campos（震央距離 $32 \mathrm{~km}$ ）で得られた加速度波形か
表- 2 計算に用いた速度構造

\begin{tabular}{|c|c|c|c|c|c|c|}
\hline $\begin{array}{l}\text { 深度 } \\
(\mathrm{km})\end{array}$ & $\begin{array}{l}\text { 厚さ } \\
(\mathrm{km})\end{array}$ & $\begin{array}{c}V p \\
(\mathrm{~km} / \mathrm{s})\end{array}$ & $\begin{array}{c}\mathrm{Vs} \\
(\mathrm{km} / \mathrm{s})\end{array}$ & $\begin{array}{c}\text { 密度 } \\
\left(\mathrm{g} / \mathrm{cm}^{3}\right)\end{array}$ & Qp & Qs \\
\hline 0.00 & & & & & & \\
\hline \multirow{2}{*}{0.035} & 0.035 & 1.84 & 0.50 & 2.2 & 100 & 50 \\
\hline & 0.120 & 1.90 & 0.65 & 2.2 & 100 & 50 \\
\hline 155 & 0.06 & 2.02 & 0.77 & 2.2 & 100 & 50 \\
\hline 0.215 & 0.585 & 2.10 & 0.80 & 2.2 & 100 & 50 \\
\hline 0.80 & 2.20 & 3.60 & 1.80 & 2.3 & 200 & 100 \\
\hline 3.00 & 5.00 & 4.70 & 2.60 & 2.5 & 300 & 150 \\
\hline 8.00 & 5.00 & 5.70 & 3.30 & 2.6 & 300 & 150 \\
\hline 13.00 & 7.00 & 6.60 & 3.70 & 2.8 & 500 & 250 \\
\hline 20.00 & 5.00 & 6.90 & 3.90 & 2.9 & 500 & 250 \\
\hline 25.0 & 7.00 & 7.00 & 4.00 & 3.0 & 500 & 250 \\
\hline 2.00 & & 7.90 & 4.40 & 3.2 & 1000 & 500 \\
\hline
\end{tabular}

ら求められた経験的震源時間関数を用いた (Somerville et al, 1991).この余震は関東地震と同 じ低角逆断層型の震源メカニズムをもち, 地震モ一 メントは $2 \times 10^{26} \mathrm{dyne}-\mathrm{cm}$, 断層面の長さ, 幅はそれぞ れ $25 \mathrm{~km}, 20 \mathrm{~km}$ でライズタイムは 2 秒である. これ に基づき, 1923 年関東地震の断層面（長さ $130 \mathrm{~km}$,

幅 $70 \mathrm{~km}$ ）を長さ力向に 5 分割, 幅力向に 4 分割する. また, 各要素断面内ではライズタイム 2 秒を有する この経験的震源時間関数を 4 つ用いて 8 秒のライズ タイムを表現した．以上より，断層面全体では計 80 個の経験的震源時間関数が用いられた。この時間関 数の重ね合わせの個数は Joyner and Boore（1986）の 震源スペクトルの相似則を満足するものである.

地下構造モデルとしては, 表-2 に示す水平成層構 造を用いる.この地下構造のモデル化に際しては, $\mathrm{S}$ 波速度 $500 \mathrm{~m} / \mathrm{sec}$ の層が露頭しているとして， $-215 \mathrm{~m}$ までは検層結果を参考にして，それより深いところ は佐藤他（1996a）およびSato et al（投稿中）に基づ いている. 計算点はこの地下構造モデルの地表面で ある。

\section{（2）シミュレーション結果}

図-3に計算された加速度波形の NS成分を示す. 短周期地震動, 長周期地震動, それらを合成した広 带域地震動, 及びその広带域地震動の水平 2 成分の スペクトルの平均を平滑化したターゲットスペクト ルに適合させた模擬地震動の順に並べている. 模擬 地震動の時刻歴波形は, ターゲットスペクトルと広 


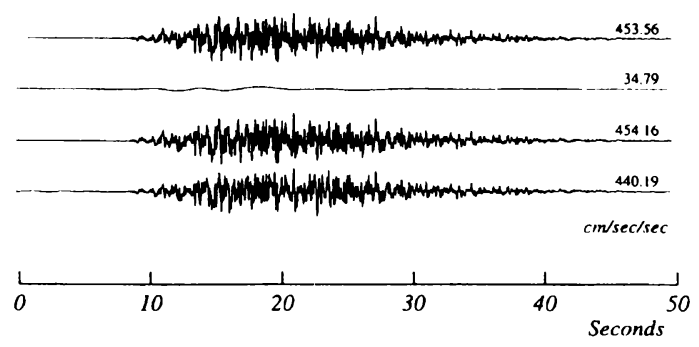

図-3 加速度の時刻歴波形（NS 成分）

（上から短周期地震動，長周期地震動，広帯域地震動,

およびターゲットスペクトルに適合させた模擬地震 動を示す)
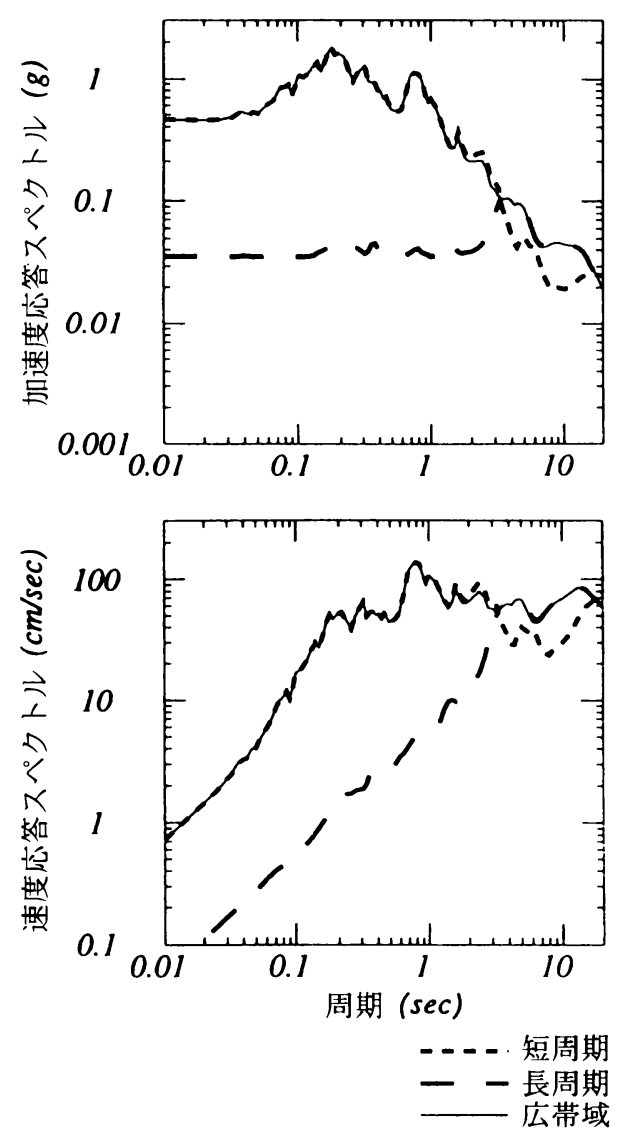

図-4 加速度及び速度応答スペクトル(NS 成分, 減衰 $5 \%$ )

帯域地震動の NS 成分の位相を用いて作成した. 図 -4に短周期地震動, 長周期地震動, それらを合成し た広帯域地震動の加速度応答スペクトルおよび速度 応答スペクトル（ともに減衰 5\%）を示す，図-5に は，広帯域地震動の応答スペクトル，ターゲットス ペクトル，及びターゲットスペクトルに適合させた 模擬地震動のスペクトルを示す。
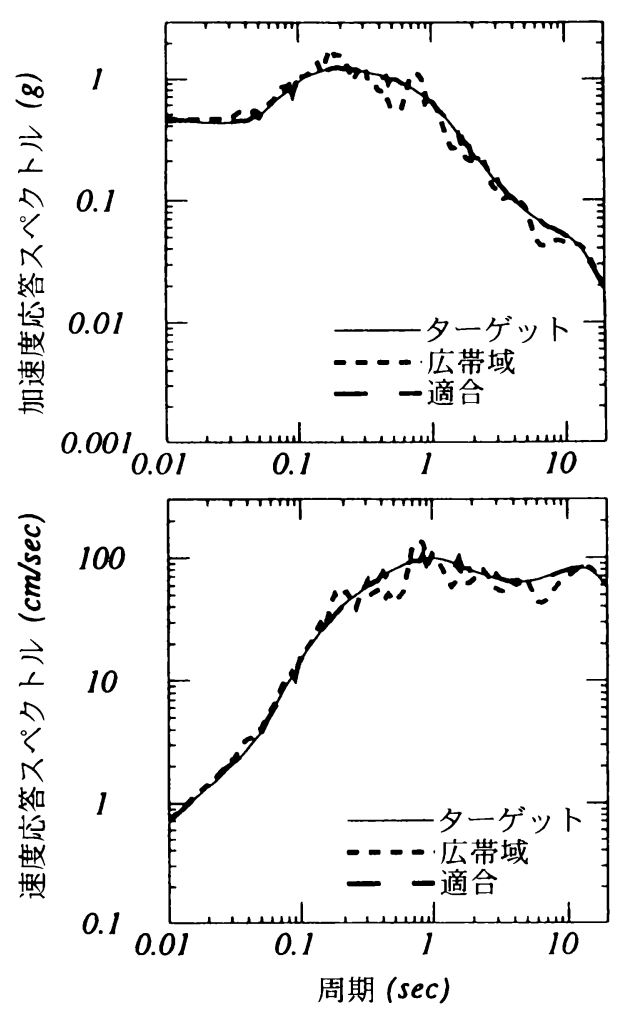

図-5 広帯域（NS 成分），ターゲット及び適合波形の加 速度及び速度応答スペクトル（減衰 $5 \%$ ）

ターゲットスペクトルを設定した理由は，すなわ ち，短周期帯域のシミュレーションで用いた経験的 震源時間関数は 1985 年ミチョアカン地震の余震の強 震記録から求めたものであり, スペクトルの細やか なピークや谷が 1923 年関東地震による東京湾口部の 地震動を正確に反映しているとは限らないからであ る. ターゲットスペクトルは広帯域地震動の水平 2 成分のスペクトルの平均を平滑化して求めた.

得られたターゲットスペクトルは, 周期 1 秒付近 で約 $100 \mathrm{~cm} / \mathrm{sec}$ の值をとる. 長周期帯域のスペクトル は周期約 12 秒を中心とする大きなピークをもつ.

\section{4. 相模トラフの将来地露の震源モデル}

\section{(1) 概要}

相模トラフにおける将来の大地震では, 1923 年関 東地震の場合とは異なった滑り分布及び震源（破壊 開始点）位置が予想され，その断層破壊モデルには 不確定性が存在する. また, 破壊伝播速度及び立ち 上がり時間についても不確定性がある.したがって, 
地震動評価の信頼性を高めるためには, 各種断層パ ラメータの変動を考慮して時刻歷波形を計算し，そ の平均像とばらつき具合を知ることが重要である.

ここでは, 相模トラフにおける将来地震の震源モ デルのモデル化について述べる．ここで, 断層面の 幾何学的形状のモデルは, 3 章と同じものを用いた.

\section{（2）破譬伝播速度の設定}

これまでの多くの地震の解析例から, 破壊伝播速 度の平均的な值は経験的に $\mathrm{S}$ 波速度の 0.8 倍である ことが知られている. 1923 年関東地震の断層面の存 在する深さ $2 \mathrm{~km}$ から $32 \mathrm{~km}$ の位置における $\mathrm{S}$ 波速度 の平均值は $3.7 \mathrm{~km} / \mathrm{s}$ である (Sato et $\mathrm{al}$,投稿中) こと から, 本検討ではその 0.8 倍である $3 \mathrm{~km} / \mathrm{s}$ を破壊伝播 速度の中央値として採用した。

破壊伝播速度のばらつきを考えるにあたって，標 準偏差 $0.5 \mathrm{~km} / \mathrm{sec}$ の正規分布を仮定した，具体的には 破壊伝播速度の（中央值一標準偏差），（中央値 + 標準偏差）の值は $2.5 \mathrm{~km} / \mathrm{s}, 3.5 \mathrm{~km} / \mathrm{s}$ である.

これらの異なった破壊伝播速度に対して計算され た地震動の応答スペクトルを平均する際には, 破壊 伝播速度に関して仮定された確率密度分布関数（正 規分布）を考慮した重みを用いるものとする．すな わち正規分布の密度関数を，(中央值一標準偏差）, 中央値，(中央值十標準偏差）を離散点としてモデ ル化した，その際，重みの合計が 1 となる前提条件 のもとに分布関数の形を考慮して, 中央值の重みを 0.45, (中央值士標準偏差) の重みを 0.275 と仮定し た.

\section{（3）立ち上がり時間の設定}

立ち上がり時間は断層面上のある位置における滑 りの継続時間を表す.ここでは, Somerville 他 (1993) が地款内地震について求めた地震モーメントと立ち 上がり時間の経験的関係を参考にして, 沈み込み境 界（サブダクションゾーン沿い）の地震における同 様な関係を推定した. 図- 6 中の白丸は, Somerville 他（1993）が地殼内地震の検討に用いた 11 個の地震 の地震モーメントと立ち上がり時間の関係を示す. このデータを基に地款内地震の立ち上がり時間 $\mathrm{T} r$ と地震モーメントM o の間の関係式は次の通りであ る.

$$
\mathrm{Tr}=1.72 \times 10^{-9} \times \mathrm{M} \mathrm{o}^{1 / 3}
$$

一方, 沈み込み境界の地震に関しては, ソースイ ンバージョン結果に基づいて不均質滑りモデルの地 震モーメントと立ち上がり時間の関係が検討できる 例は，わずかに2 例しかない.この結果を図-6中に

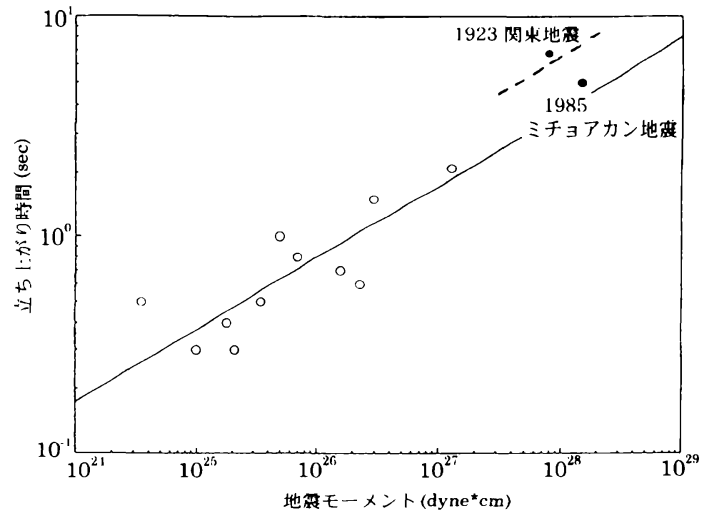

図- 6 地殼内地震の地震モーメントと立ち上がり時間との 関係.（1923 年関東地震と 1985 年ミチョアカン地震 の関係も記載)

黒丸で示す. 1923 年関東地震の立ち上がり時間 6.8 秒の推定值は遠地実体波のデータから導かれている が（Wald and Somerville，1995），強震動データの不 足及び遠地実体波のデータが疎らであり，信頼性の 点で確実なものではない.メキシコで発生した 1985 年ミチョアカン地震の立ち上がり時間の推定值 5 秒 は強震動データ及び遠地実体波データに基づいて Mendoza and Hartzell（1989）によって求められたもの

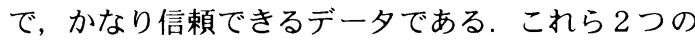
地震の断層面の滑りの平均值は各々 $3.5 \mathrm{~m}, 1.4 \mathrm{~m}$ であ る. 1985 年ミチョアカン地震の滑りの平均值は, こ の規模の地震としてはかなり小さい值である.この 滑りの平均值の小ささは立ち上がり時間の值が小さ いことと関係があると考えられる. そこで，ここで はWald and Somerville（1995）の結果も踏まえてマ グニチュード 8 の沈み込み境界の地震の立ち上がり 時間の平均值を 6 秒程度と推定し，立ち上がり時間 $\mathrm{T} \mathrm{r}$ と地震モーメントMoの関係式として次の式を用 いることとした.

$$
\mathrm{Tr}=3.0 \times 10^{-9} \times \mathrm{Mo}^{1 / 3}
$$

この式から，1923 年関東地震について，立ち上がり 時間 6 秒が得られる. 沈み込み境界の地震の立ち上 がり時間のばらつきに関しては，他に参考となるデ 一タがないことから, 地款内地震のデータから導か れた立ち上がり時間の標準偏差を表す倍率 1.4 倍と いう数値をそのまま用いる。これによれば立ち上が り時間の（中央值一標準偏差）および（中央値＋標 準偏差）の具体的な值としてそれぞれ，4秒，8秒が 得られる.

相模卜ラフの想定地震の立ち上がり時間の不確定 性に加えて短周期の地震動シミュレーションにおい てサブイベントの経験的震源時間関数として用いる 
表- 3 仮定された立ち上がり時間の分布

\begin{tabular}{|c|c|c|}
\hline $\begin{array}{l}\text { 主イベントの } \\
\text { 立ち上がり時間 }\end{array}$ & $\begin{array}{l}\text { サフイベントの } \\
\text { 立ち上がり時間 }\end{array}$ & 重み \\
\hline 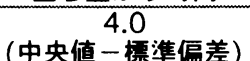 & $\begin{array}{c}1.5 \\
\text { (中央値) }\end{array}$ & .1375 \\
\hline $\begin{array}{c}6.0 \\
\text { (中央値) }\end{array}$ & (中央値一䉘準偏差) & .1375 \\
\hline $\begin{array}{c}6.0 \\
\text { (中央値) }\end{array}$ & $\begin{array}{c}1.5 \\
\text { (中央値) }\end{array}$ & .45 \\
\hline $\begin{array}{c}6.0 \\
\text { (中央値) }\end{array}$ & 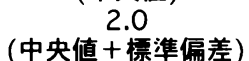 & .1375 \\
\hline $\begin{array}{c}8.0 \\
\text { (中央値+㩰準偏差) }\end{array}$ & $\begin{array}{c}1.5 \\
\text { (中央値) }\end{array}$ & .1375 \\
\hline
\end{tabular}

1985 年ミチョアカン地震の余震の立ち上がり時間の 不確定性もある。この余震の地震モーメントは, $2 \times 10^{2 i}$ dyne $\cdot \mathrm{cm}$ (Somerville 他, 1993）である.この 地震モーメントから上記の関係式を用いて立ち上が り時間の平均値を求めると 1.5 秒となり, (中央値一 標準偏差）および (中央值十標準偏差）の值として それぞれ 1.0 秒， 2.0 秒が得られる.このような考察 に基づき，短周期帯域のシミュレーションにおいて は, シミュレーションの対象となる 1923 年関東地震 の立ち上がり時間の変動とともにサブイベントの経 験的震源時間関数立ち上がり時間の推定誤差の影響 も考えた。

想定地震とサブイベントの 2 つの立ち上がり時間 の組み合わせについては, 正規分布の密度関数を 2 次元で考え，それぞれの時間軸において（中央值一 標準偏差）, 中央値, (中央値十標準偏差) を離散 点として, 5 個の立ち上がり時間の組み合わせでモデ ル化した，各離散点における重みは，合計が 1 とな ることを前提条件として，分布関数の形を考慮して 仮定した。このようにして考えた組み合わせと重み を表-3 に示す.

\section{（4）滑り分布モテルの作成}

本研究では Somerville 他（1993）の考え方に基づ いて将来の相模トラフ地震を想定して 8 つの滑り分 布モデルを作成した。この滑り分布モデルに滑りの 大きさのコンター及び陰影を付けたものを図７に， また滑りベクトルを図 8 に示す.

滑り分布の作成においては空間に関する波数スぺ クトルを利用した。波数スペクトルの振幅成分はア スペリティ（大きく滑る領域）のサイズおよび強度 を決定する．ここでは，8つの滑り分布モデルのす べてが, Somerville他（1993）に示された 11 個の地 震の波数スペクトル振幅の平均特性に従っている.

波数スペクトルの位相成分はアスペリティの位置 を決定する. 各地震において類似の特性をもつ振幅
成分とは異なり，位相成分はアスペリティの位置の 相違を反映して地震ごとにその值が異なる。したが って，ここでは波数スペクトルの位相成分をコント ロールするための異なる乱数を選定し，位相成分が ランダムに変化した 8つの異なる滑り分布モデルを 作成した。

各要素断層の滑り角は，中央值が $135^{\circ}$ で, $100^{\circ}$ から $170^{\circ}$ の範囲に入る值をランダムに発生させて 決定した. 中央值の值は1923 年関東地震の滑り角を 参考とした。

これら 8 つの滑り分布モデルを用いて計算した地 震動の応答スペクトルの平均値を求める際には，各 滑り分布モデルの発生可能性が同じ程度であると考 え, 各モデルに対して $1 / 8$ の重みを用いることにした.

\section{（5）震源位置（破壊開始点）の選定}

1923 年関東地震における震源は断層の北西端部に 位置していたが, 将来発生する地震では, 断層走向 に沿ってどの位置が震源となっても不思議ではない したがってここでは断層走向に沿って等間隔に 4 筒 所の震源を仮定した. 1923 年関東地震の震源深さは 断層面のほぼ中央であり端部ではなかったことを参 考として，ここでは震源深さとして断層面の幅方向 において中央部付近の上部側と下部側の 2 箇所を選 んだ。すなわち, 本検討で用いる震源位置は, 断層 走向方向 4 箇所, 断層幅方向 2 箇所の組み合わせか ら合計 8 箇所となる.これらの震源位置は図- 7, 図 - 8 において星印で表示している.この 8 筒所には関 東地震の震源は含んでいない。これらの震源位置を 破壊開始点と考えて計算された地震動の応答スペク トルの平均值を求める際に, 各位置は同様にあり得 るものと考えて, 各モデルに対して 1/8 の重みを採用 した.

\section{（6）シミュレーションで用いる変動パラメータ のまとめとケース数}

これまで 8 つ滑り分布モデルのセット，8箅所 の震源位置のセット, 3 つの破壊伝播速度のセット， 3 つの主イベントの立ち上がり時間のセット， 3 つ のサブイベントの立ち上がり時間のセット, および これらの各パラメータ值に割り当てられた重みにつ いて説明した。 以下では, これらの断層パラメータ の変動を組み合わせた, $8 \times 8 \times 3 \times 5=960$ ケースにつ いてシミュレーションを行い, 時刻歴波形を生成し た. 

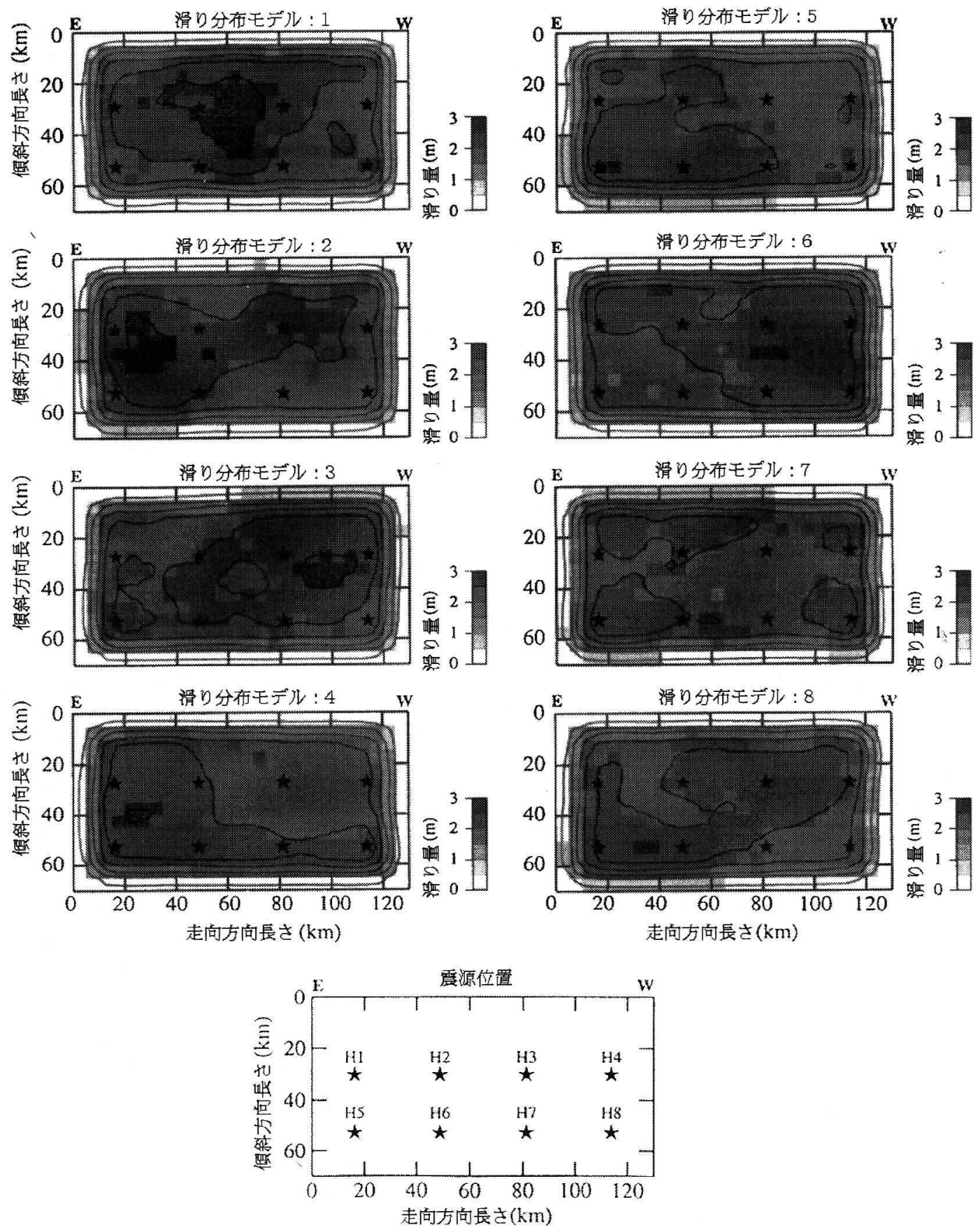

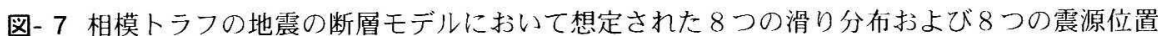
(滑り量分布は等高線及び陰影で表示) 

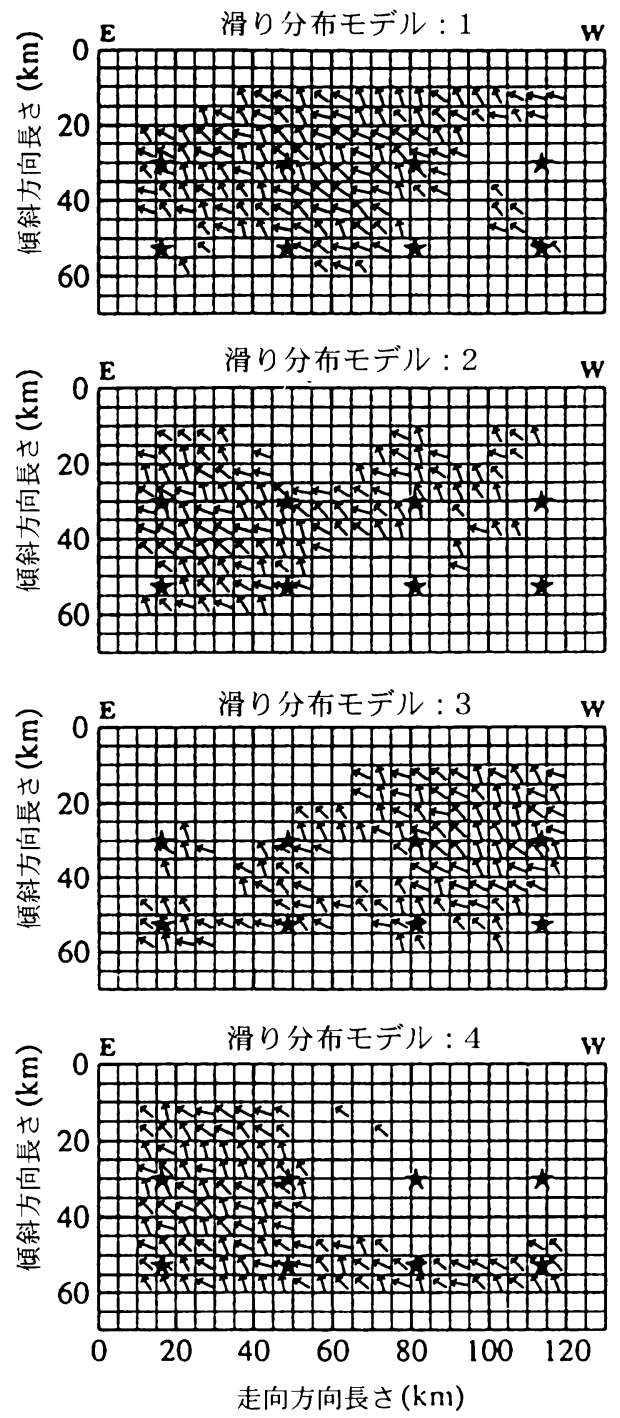
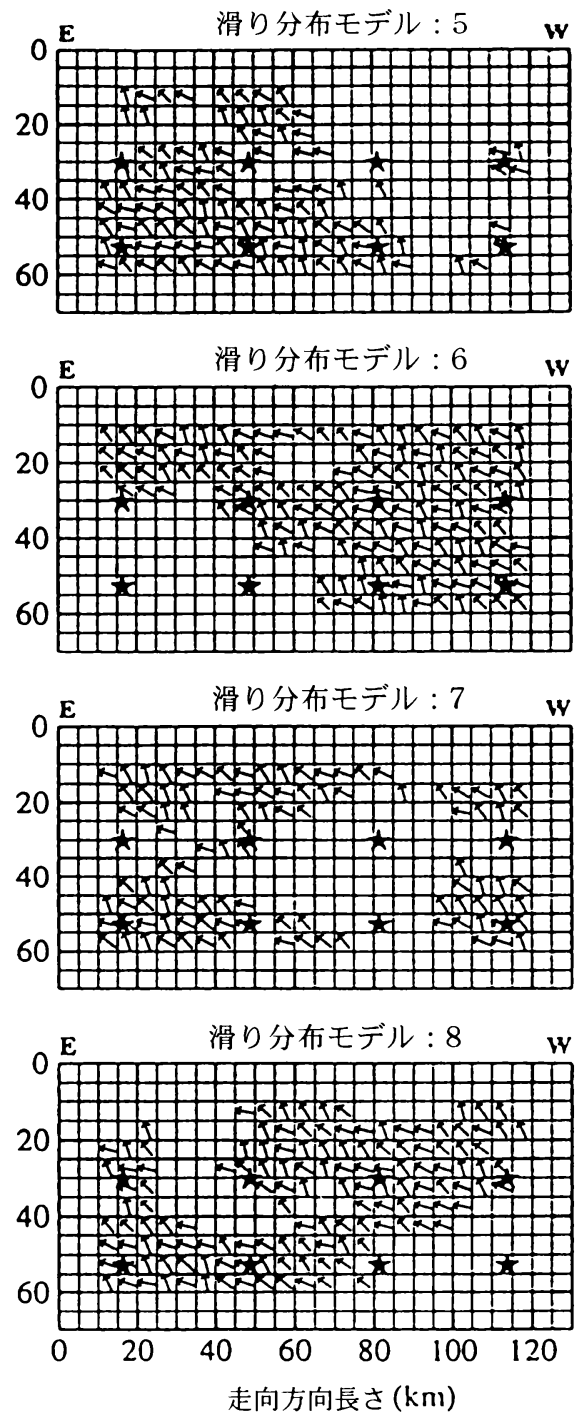

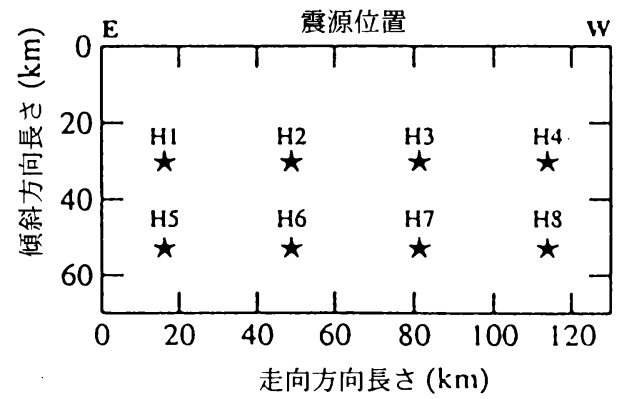

図- 8 相模トラフの地震の断層モデルにおいて想定された 8 つの滑り分布および 8 つ震源位置 (大きく滑る部分の滑りの向きをべクトルで表示) 

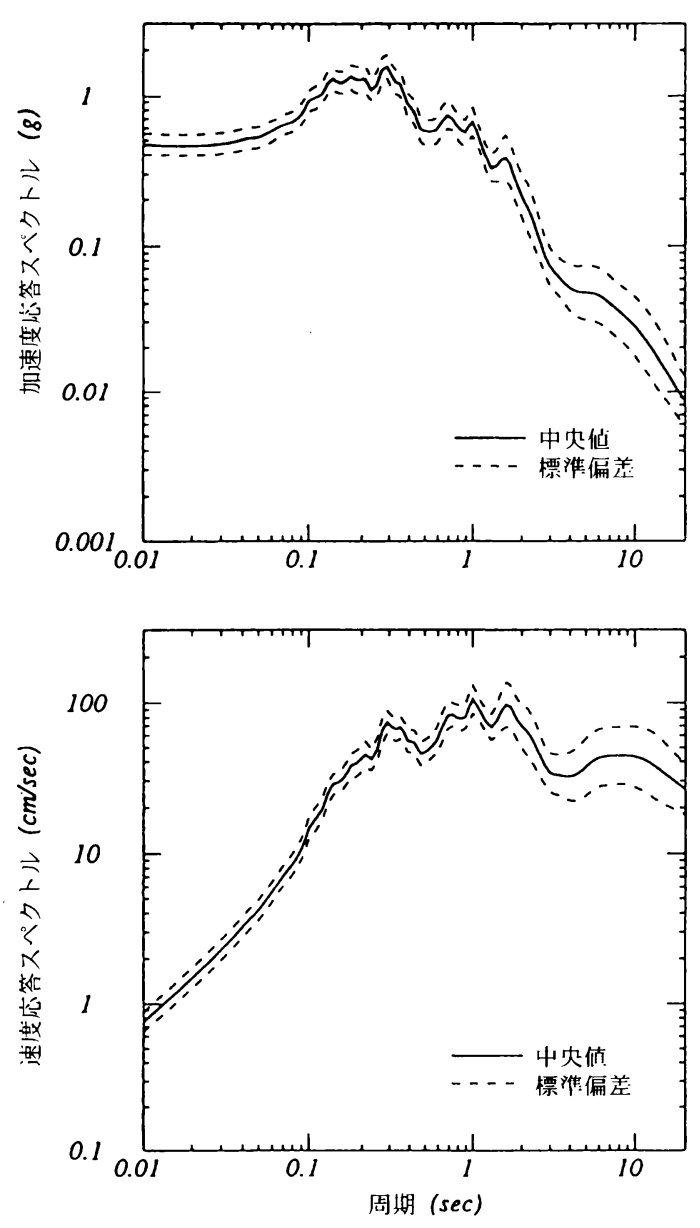

図- 9 全ての震源パラメータの変動を考慮した場合の応

答スペクトルの中央値と標準偏差

\section{5. 相模トラフの将来の地震動の推定}

\section{(1) 概要}

ここでは, 前章の断層パラメータを用いた計算結果 より，まず応答スペクトルの中央值と標準偏差を示 す。次いで, 応答スペクトルの震源パラメータへの 依存性を考察する.さらに実現象をモデル化するに 際しての不確定性をも考慮した応答スペクトルの標 準偏差を求め, 最終的な平滑化スペクトルの中央値 と標準偏差を求めた．最後に，計算された 960 個の 時刻歴波形の中からこの平滑化スペクトルの中央值 とばらつきに適合する10個の時刻歴波形のサブセッ トを予測地震動の代表例として選択した.

地震動を求める点は 3 章と同じであり, 図-1 に示 すサイトAである．震源とサイト間の伝播経路に沿 った波動伝播効果を表すグリーン関数の計算にも 3
章の水平成層地盤構造モデルを採用した.

(2)各パラメータの変動を考虑した応答スペクトル の中央値および標準偏差

計算された時刻歴波形のNS成分と EW 成分の応答 スペクトル間で系統的な相違が小さいことがわかっ たので, 水平 2 成分の応答スペクトルの平均をとつ て結果を表示する. 前章の各パラメー夕值に割り当 てられた重みを用いて，全セットに対する応答スペ クトルの中央值および標準偏差を計算した。 その結 果を図-9に示す.この図に示された標準偏差は全て のパラメータの変動による応答スペクトルのばらつ き具合を表している.

\section{（3）応答スペクトルの署源パラメータヘの依存性 (パラメトリック標準偏差およびモテリングに}

\section{よる不確定性）}

変動を考えた 4 個の震源パラメー夕は, 滑り分布, 震源位置, 破壊伝播速度, および立ち上がり時間で ある. それぞれのパラメータの変動に伴う応答スペ クトルのばらつき具合を他のパラメータの変動がな いものとして計算した結果を図-10 に示す. また,

図-11に, 自然対数表示の加速度応答スペクトルに おける標準偏差を周期の関数として示す.この図か ら次のことが分かる. 応答スペクトルの最大の変動 は立ち上がり時間に関するものである. 次に大きな 変動は破壊伝播速度に関するものである. 周期 4 秒 までは周期が長くなるにしたがって応答スペクトル のばらつきが大きくなり, 周期 4 秒以上の長周期帯 域ではばらつきは減少する，3番目に大きな影響を 及ぼす変動は震源位置に関するものである. 応答ス ペクトルのばらつきは周期が長くなるにつれて次第 に大きくなる. 最も小さい変動は滑り分布モデルに 関するものである. 今回のシミュレーションでは, 滑り分布モデルに関する変動が最も小さくなったが, これは, Takeo and Kanamori（1992,1997）の結果と異 なっている.この理由は今回用いた滑り分布が Takeo らと比較してかなり滑らかであること, および最大 滑り量が $3 \mathrm{~m}$ 程度と Takeo らの $10 \mathrm{~m}$ と比較して小さい ことが考えられる.このような滑り分布モデルとな った原因として, 滑り分布モデルの作成に際して, 内陸地震デー夕を用いていること, および波数スぺ クトルで滑り分布を表す際のモデル化の精度の問題 の 2 つが考えられるが, この点に関しては, 今後の 検討課題と考えている.

図-11 には異なるパラメータの影響に関して相関 

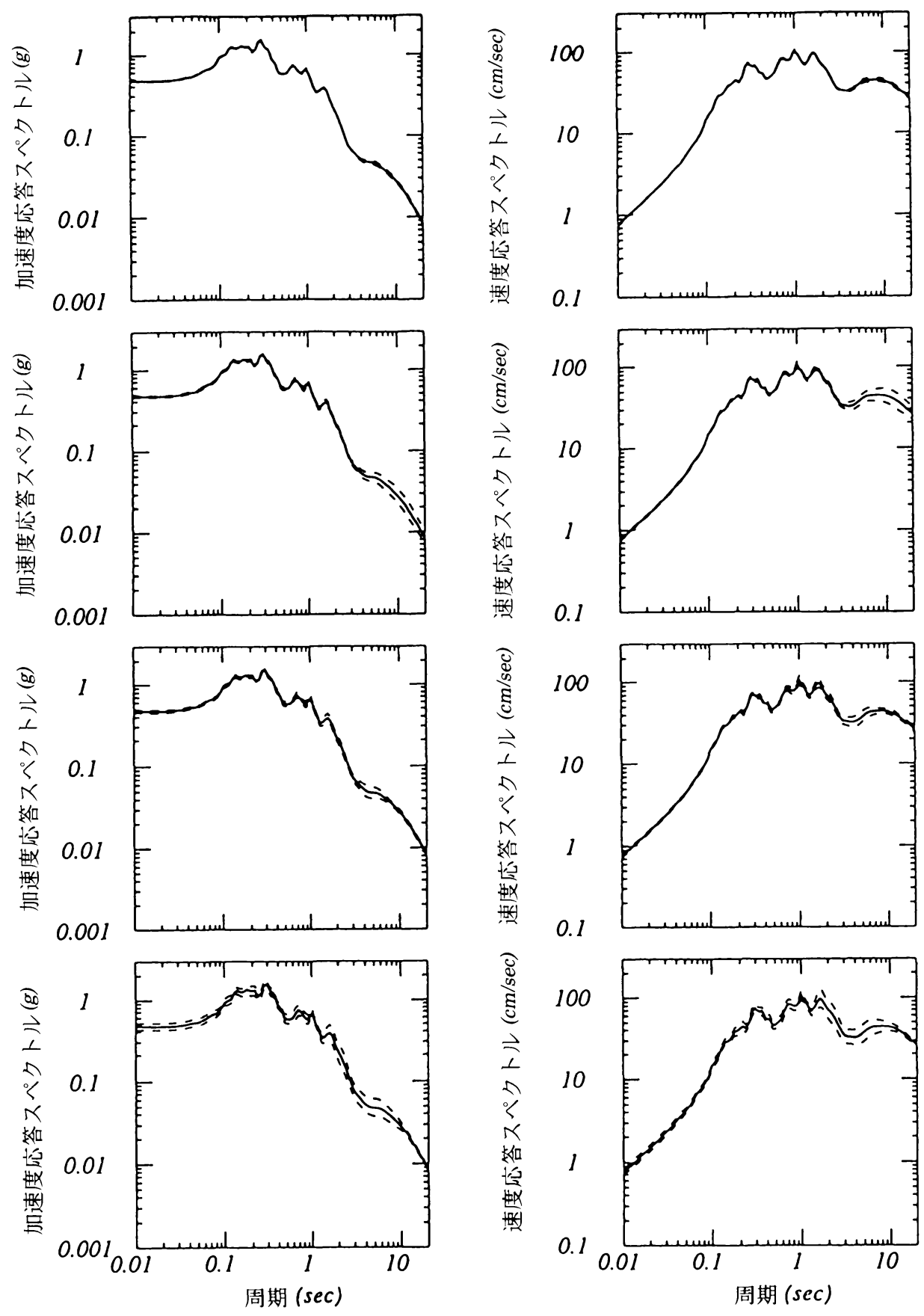

(a)

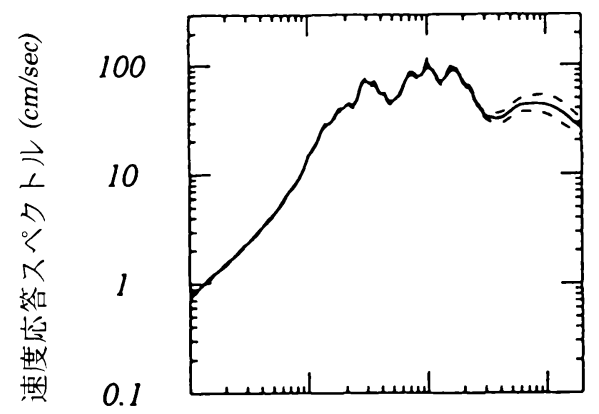

(b)

(c)
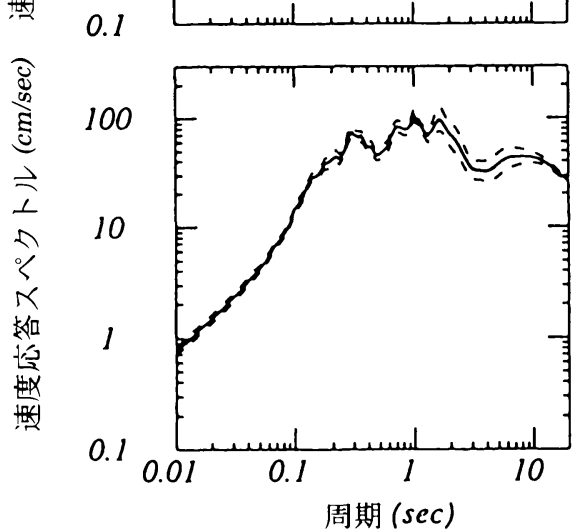

(d)

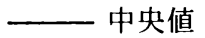

- - - - 標準偏差

図-10 個々の震源パラメータの変動に対する応答スペクトルの中央值と標準偏差

（a）滑り分布モデル；（b）震源位置：（c）破壊伝播速度；（d）立ち上がり時間 


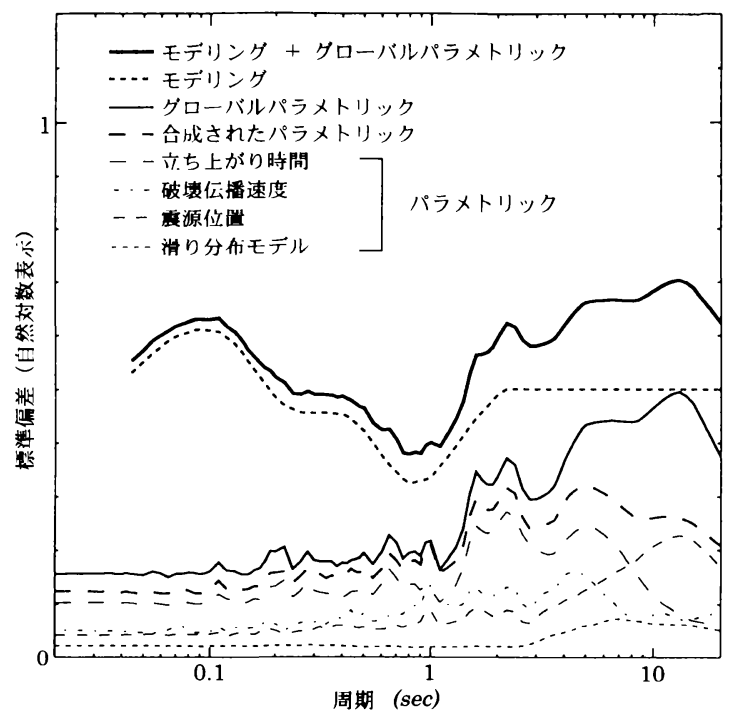

図-11 全ての震源パラメータの変動に対する加速度応答 スペクトルの標準偏差（中太実線），モデリング自 体の不確定性による標淮偏差（中太破線），および その両者を考虑した標準偏差（太実線）。個々の震 源パラメータの変動に対する標準偏差 (下側の 4 つ の線），および個々の震源パラメータの変動が応答 スペクトルに及ほす影噼は独立であると仮定して 個々の震源パラメータの変動に対する標準偏差か ら求めた全ての震源パラメータの変動に対する標 準偏差（間隔のあいた太破線）

がないと仮定して個々のパラメータの変動に関する 標準偏差をすべて合成（自乗和の平方根）すること によって求めた標準偏差も示す，合成されたパラメ トリック標準偏差はシミュレーションの全セットか ら求めたグローバルパラメトリック標準偏差よりも 小さい.このことはパラメータの影響に関して何ら かの相関があることを示している. 別途行った検討 から立ち上がり時間と破壊伝播速度の間に相関があ ることがわかった.

応答スペクトルの第二の不確定性であるモデリン グ自体の不確定性は，震源パラメータが既知である 地震に対して本方法を適用して求められた合成地震 動之観測地震動との相違から評価される。しかしな がら，厳密な意味で震源パラメータが完全に既知で ある地震は存在せず, この第二の不確定性のみの評 価を行うことは現実には難しい。本研究では， Somerville et al (1991) が 1985 年ミチョアカン地震 に対して評価したこのモデリングによる不確定性の 影響を用いることとし，図-11 にその結果を併記し
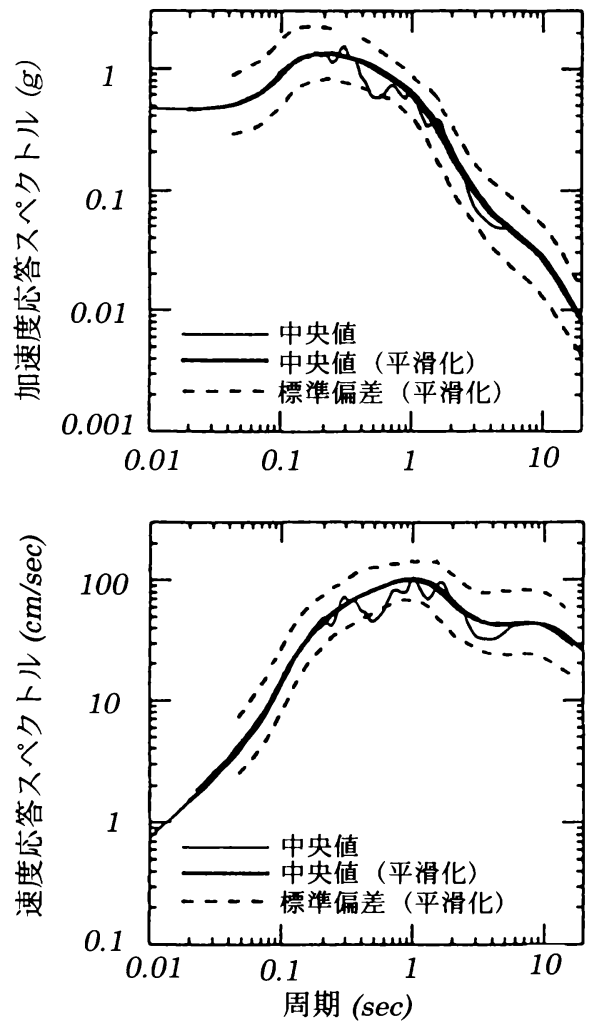

図-12 本検討で得られた応答スペクトルの中央值(図- 9) と平滑化応答スペクトルの中央值とその標準偏差

ている. Somerville et al（1991）の結果にも震源パラ メー夕の不確定性が完全に排除されているわけでは ないが, 1985 年ミチョアカン地震は比較的精度の良 いデータから震源パラメータが推定されている地震 であることから採用した. 1985 年ミチョアカン地震 のシミュレーションの際には短周期地震動のシミュ レーションのみを実施しているので, 周期 3 秒以上 の長周期帯域における不確定性は不明である。 そこ で，図-11 では短周期帯域における不確定性の平均 的な值である数值 1.65 （自然対数表示で 0.50）を長 周期帯域における不確定性として見積もった．以上 の二つの不確定性を考慮した応答スペクトルの標隻 偏差は，それぞれの不確定性による標準偏差の自然 対数の自乗和の平方根を計算することにより評価さ れる. その結果は図-11 に併記されており，これに よって 2 種類の不確定性を考慮した応答スペクトル の標準偏差が得られた．この標準偏差は，第二の不 確定性が完全に分離されていないため, 過大評価と なっているおそれがあることに留意すべきである. 

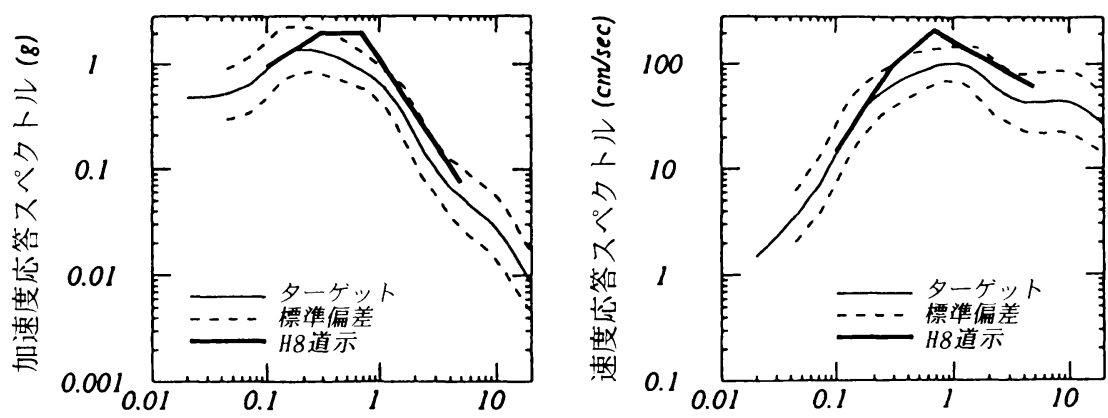

(a)
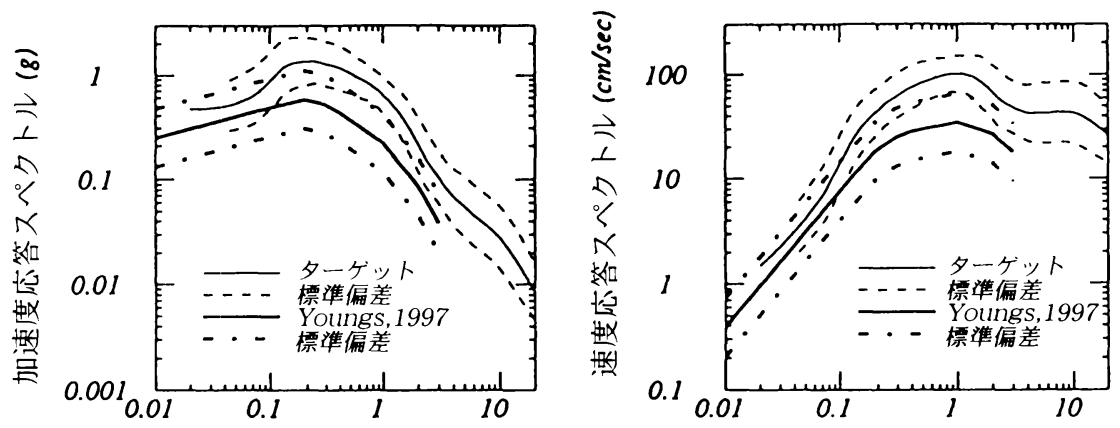

(b)
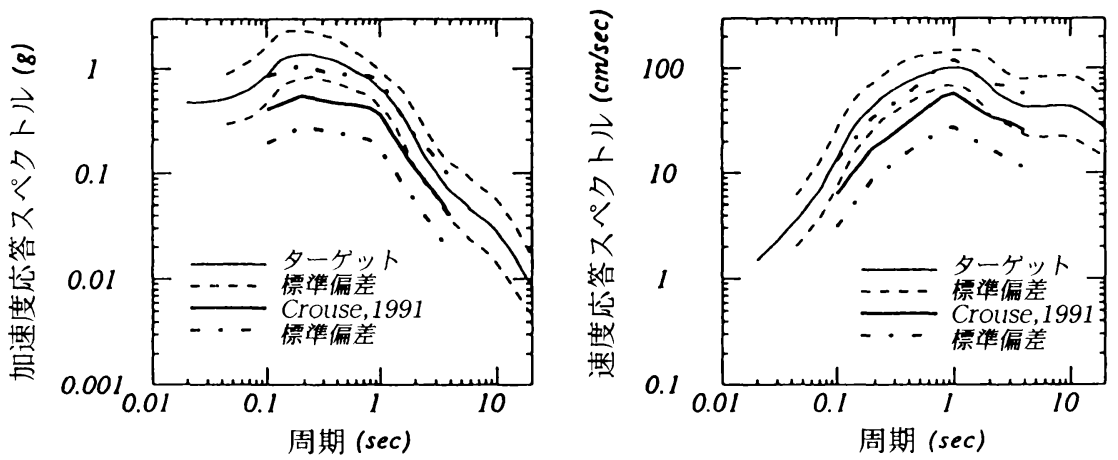

(c)

図-13 平滑化された応答スペクトルと他の経験的応答スペクトルとの比較

(a) 地盤種別 I に対するH 8 道示スペクトルとの比較

(b) Youngs(1997)の経験的なスペクトルとの比較

(c) Crouse(1991)の経験的なスペクトルとの比較

\section{（4）平滑化スペクトルの作成}

平滑化スペクトルは 960 ケースのシミュレーショ ンから得られた応答スペクトルの平均值を滑らかな カーブで表現したものである. 平滑化スペクトルは, 当該サイトで実際に生じると予想される平均的な地 震動特性を反映していないと考えられるスペクトル のピークおよび谷を目視によって除外して作成した。 その結果を図-12 に示す.
平滑化スペクトルの標準偏差は Abrahamson et al （1990）の方法に従い前述の 2 種類の不確定性によ る影響を考虑して作成した。

図-12 には 2 種類の不確定性を考慮した場合の標 準偏差を平滑化スペクトルとともに示している.こ の図-12 が相模トラフで将来起こる地震によるサイ トAにおける地震動の平滑化スペクトルとそのばら つきに関する最終的な結果である. 
表- 4960 ケースのシミュレーション結果を代表するた めに選択された10 ケースの時刻歴波形の計算に用 いた震源パラメータ

\begin{tabular}{|c|c|c|c|c|}
\hline $\begin{array}{l}\text { サンブル } \\
\text { 番号 } \\
\end{array}$ & $\begin{array}{l}\text { スリッブ } \\
\text { モデル }\end{array}$ & 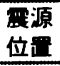 & $\begin{array}{c}\begin{array}{c}\text { 破袋速度 } \\
(\mathrm{km} / \mathrm{s})\end{array} \\
\end{array}$ & $\begin{array}{l}\text { 立ち上がり時間の組み合わせ } \\
\text { (主要動+サプイベン, }\end{array}$ \\
\hline 7 & 1 & 1 & 3.0 & $8.0+1.5$ \\
\hline 2 & 2 & 2 & 3.0 & $4.0+1.5$ \\
\hline 3 & 3 & 3 & 2.5 & $8.0+1.5$ \\
\hline 4 & 4 & 4 & 3.5 & $4.0+1.5$ \\
\hline 5 & 5 & 5 & 3.0 & $6.0+2.0$ \\
\hline 6 & 6 & 6 & 3.0 & $6.0+2.0$ \\
\hline 7 & 7 & 7 & 2.5 & $6.0+2.0$ \\
\hline 8 & 8 & 8 & 3.0 & $6.0+1.5$ \\
\hline 9 & 1 & 2 & 2.5 & $4.0+1.5$ \\
\hline 10 & 3 & 2 & 3.5 & $6.0+1.0$ \\
\hline
\end{tabular}

（5）平滑化スペクトルと経験的なスペクトルとの 比較

図-13(a) は平滑化応答スペクトルと地盤種別 I に対する平成 8 年版道路橋示方書耐震設計編に規定 されるスペクトルとを比較したものである. 0.2 秒よ り短い周期帯域では平滑化スペクトルと道示スペク トルはほぼ重なっている. 周期 0.2 秒から 5 秒の間で は, 道示スペクトルの方が大きい.

平滑化応答スペクトルと沈み込み境界沿いの地震 に対する地震動の経験的距離減衰式に基づいたスぺ クトルモデル (Youngs et al, 1997 およびCrouse,1991) との比較を行った結果を図-13 の(b)および(c)に示 す. Youngs et al (1997) のスペクトルは岩盤サイト に対するもので, Crouse（1991）のスペクトルは硬 い地盤サイトに対するものである。これらの経験的 な応答スペクトルは平滑化応答スペクトルの（中央 值一標準偏差）程度かそれよりもやや小さい值を示 す. 標準偏差も本検討の結果の方が小さい.

経験的な地震動の距離減衰式は震源近傍ではデー 夕が少なく, かつ近距離のデータの多くは1985 年ミ チョアカン地震のものである. この1985 年ミチョア カン地震は大きな破壊領域上で平均的には小さな滑 りしか生じていないので, 震源近傍では大きな地震 動が生じていない，結果的にはこれが経験的な地震 動の距離減衰式によるスペクトルが小さな值となっ ている一つの原因と考えられる.

\section{（6）シミュレーション結果を代表する 10 ケースの 時刻歴波形セットの選定}

960 ケースのシミュレーション波の中から10 ケー スの時刻歴波形のセット（1 ケースで NS, EW 成分 があるので計 20 波）を数多く作成し, 各セットの応 答スペクトルの平均值とばらつきが平滑化応答スペ
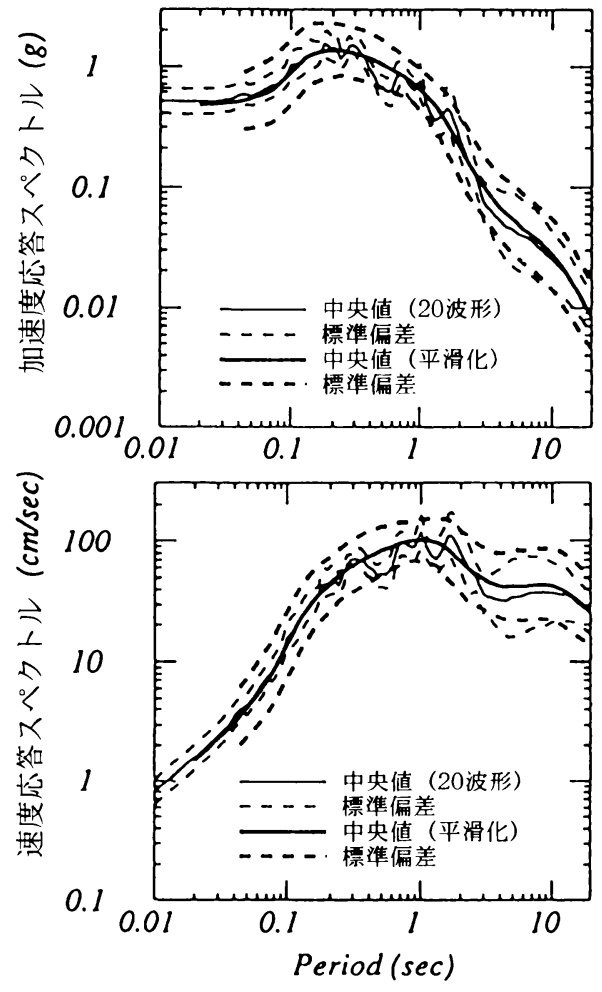

図-14 平滑化された応答スペクトルと10 ケース（20 波形） の時刻歴波形の応答スペクトルの中央値と標準偏差 の比較

クトルの平均值とばらつきに最も近い1 セットを選 択した。これら10 ケースの時刻歴波形（計 20 波） の応答スペクトルの中央值と標準偏差を平滑化応答 スペクトルのそれらと比較したものを図-14 に示す. 表- 4にこれらの時刻歴波形の計算に用いた震源パ ラメータのリストを示す. 10セットの加速度, 速度, 変位の時刻歴波形の一部をそれぞれ図-15 (a), (b), (c)に示す.

これらの10ケースの時刻歴波形は相模トラフで起 こる大地震によるサイト $\mathrm{A}$ の地震動の平均的特性と そのばらつきを表すという観点で使用できる． 3 章 と異なり，個々の時刻歴波形を平滑化応答スペクト ルに適合させることは行っておらず, 各時刻歴波が それぞれ固有の地震動レベルと応答スペクトルの山 谷を有している.

図-15(c)に示された静的変位は地震による地款変 動の結果生じるものに対応する. その静的変位の方 向（南東方向）は1923年関東地震の後に観測された ものと整合している（Wald and Somervile, 1995, Figure 9）.10ケースの静的変位の平均（約 $1 \mathrm{~m} ）$ は 1923 
(a) 加速度波形
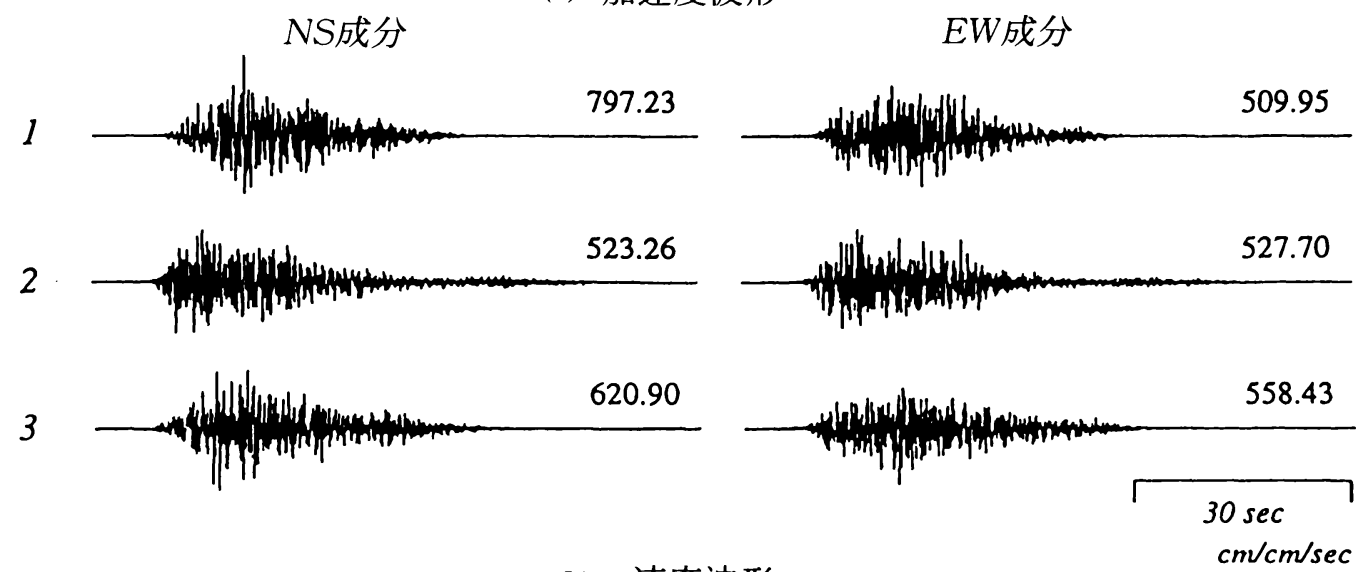

(b) 速度波形
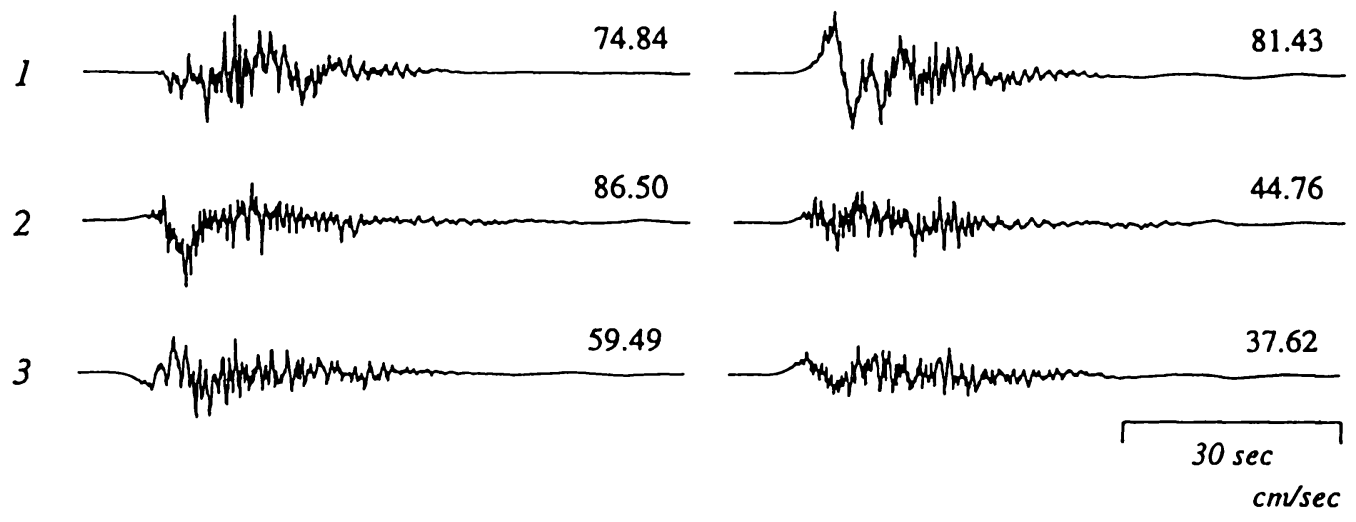

(c) 変位波形

122.22
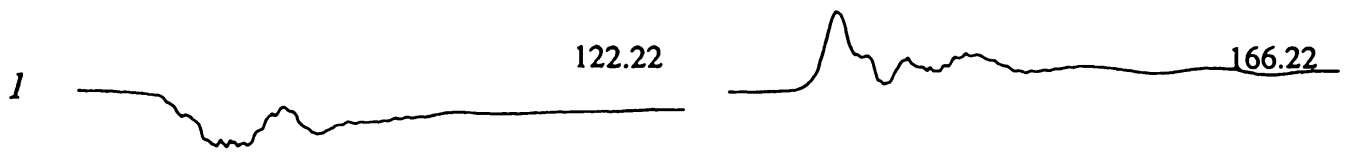

131.91

2
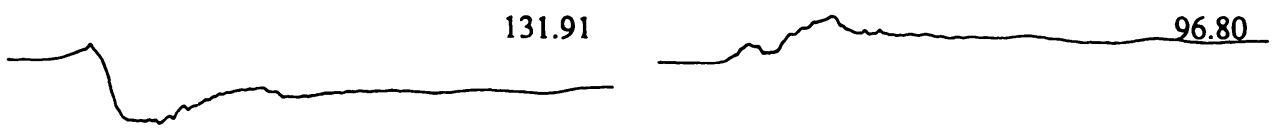

100.39

3
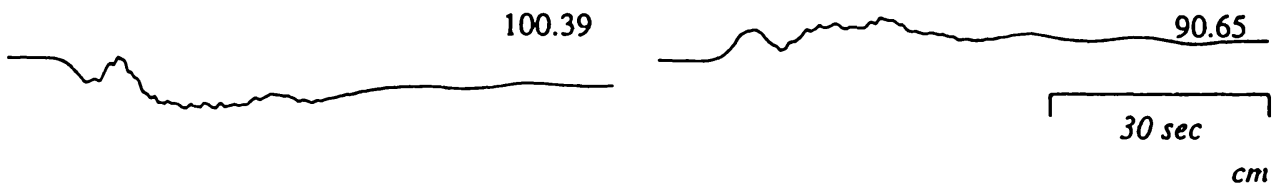

図-15 平滑化応答スペクトルを代表する 10 ケースの時刻歴波形の NS および EW 成分の一部

(a) 加速度時刻歴波形 (b) 速度時刻歴波形 (c) 変位時刻歴波形

年関東地震の後に当該サイト近傍で観測された約 3 mという值（Matu'ura et al ,1980）よりも小さいが,

これは 1923 年関東地震では, 当該サイト付近の直下
に大きなアスペリティが存在したことによると考え られる（Wald and Somerville, 1995, Figure 17）. 


\section{6. あとがき}

本検討では短周期帯域と長周期带域とで異なった 手法で地震動を作成した後, それらを合成して広帯 域地震動を求める手法を用い，1923 年関東地震によ る断層モデルを使用して, 将来大型上木構造物が建 設される可能性のあるサイトAの地震動を評価した.

本文で示したように, プレート境界型の短周期帯 域の地震動の推定に関し, 同じプレート境界型の余 震記録を用いたことが本手法の特徽の一つである. この手法によれば, 地震動を推定したい断層上で起 こった地震による記録波形がない場合でも, 短周期 帯域の地震動の推定が可能である.

次いで, 相模トラフのプレート境界付近で将来起 こる大きな地震によって, サイトAで発生すると考 えられる地震動の評価を行った．この評価では予想 される地震の震源パラメータ（滑り分布, 震源位置, 破壊伝播速度，および立ち上がり時間）の不確定性 を考慮して、これらのパラメータを組み合わせた合 計 960 ケースに対して時刻歴波形を計算し, 全ケー スの答スペクトルの中央值とばらつきを示した.

サイトAにおける地震動は, 平滑化応答スペクト ルの中央値とその標準偏差によって表した，応答ス ペクトルの標準偏差は予測される地震の震源パラメ 一夕に関する不確定性のみならず，シミュレーショ ン万法のモデリング自体に起因する不確定性の影響 も含んでいる. また, 960 ケースの時刻歴波形の中か ら, 平滑化応答スペクトルの中央值とその標準偏差 を満足するような10ケースの時刻歴波形のセットを 選択した.この時刻歴波形のセットは当該地点に建 設される構造物の動的応答解析を行う際, 有効に利 用できる。

本検討結果によって, 本研究で用いた手法は, 今 後増加が予想される断層近傍における地震動評価の 一手法として十分考慮に值するものと考えられる。 また，相模トラフで発生する大地震によるサイト A の地震動の具体的数值は類似地点の地震動を評価す る上で有用な工学的資料となるといえよう。

謝辞：本研究に御協力いただいた（株）大崎総合研 究所の渡辺孝英氏に謝意を表する。

\section{参考文献}

1) Somerville, P.G., Graves, R.W., and Saikia, C.K.: Estimation of strong motion time histories experienced by steel buildings during 1994 Northridge earthquake,

Proc. of the 11th W.C.E.E., Acapulco, Mexico, June,
1996.

2) Hartzel, S. H. and Heaton, T.H.: Inversion of strong groundmotion and teleseismic waveform data for the fault rupture of the 1979 Imperial Valley, California earthquake,Bull.Seism. Soc. Am. 83, pp.780-810, 1983.

3) Saikia, C.K.: Modified frequency-wavenumber algorithm for regional seismograms using Filon's quadrature: modeling of $\mathrm{Lg}$ waves in eastern North America. Geophys. J. Int. 118, pp.142-158, 1994.

4) Helmberger, D.V. : Generalized ray theory for shear dislocations, Bull. Seism. Soc. Am., 64, pp.45-64, 1974.

5) Somerville, P.G., Sen, M.K. and Cohee, B.P.:

Simulation of strong ground motions recorded during the 1985 Michoacan, Mexico and Valparaiso, Chile earthquakes,Bull. Seism. Soc. Am., 81, pp.1-27, 1991.

6) Wald, D.J. and Somerville, P.G.: Variable slip rupture model of the great 1923 Kanto, Japan earthquake: geodetic and body-waveform analysis, Bull. Seism. Soc. Am., 85, pp.159-177,1995.

7) 武村雅之, 池浦友則: 短周期データから見た 1923 年関 東地震の多重震源性,地震第 2 輯, 47 巻, pp.353-364, 1994.

8) 佐藤俊明, Helmberger, D.V., Somerville, P.G., Graves, R.and Saikia, C. : 1923 年関東地震（Ms 8.1）の近地方 よび震源近傍のやや長周期地震動のシミュレーショ ン, (その1) マスターイベント(1990年小田原地震, M 5.1)の震源パラメータの再評価と波形モデリングによ る 1 次速度構造モデルの評価, 日本地震学会講演予稿 集, 1996 年度秋季大会, A63, (1996a).

9）野澤貴,武村雅之, 池浦友則,山中浩明：地震動のやや 長周期成分からみた 1923 年関東地震の震源特性, 地 震第 2 輯, 48 巻, pp. 331-340, 1995.

10) Joyner, W.B. and Boore, D.M. : On simulating large earthquakes by Green's function addition of smaller earthquakes, un Earthquake Source Mechanics, S.da.J.Boatmight, and C.H. Scholtz (Editors), Mauries Easing Series 6, Americal Geophysical Union Monograph, 37, pp.269-274, 1986.

11) Graves, R. W., Somerville, P.G., Sato, T. and Kataoka, S.: Estimates of long-period strong ground motions in the Kanto District from the 1923 Kanto earthquake, Proc. of the 9th Japan Earthquake Engineering Syposium, Tokyo, Vol.1, pp.577-582, Dec. 1994.

12) Sato, T., Helmberger, D.V., Somerville, P.G., Graves, R.W.and Saikia, C.K. : Estimates of regional and local strong motions during the great 1923 Kanto, Japan, Earthquake (Ms 8.2), Part 1 : Source estimation of a calibration event and modeling of wave propargation paths, Bull. Seism. Soc. Am. (submitted). 
13) Somerville, P.G., 入倉孝次郎, 沢田純男, 岩崎好規, 田居優・伏見実：地震断層の滑り変位量の空間分布の 検討,第 2 回地震工学研究発表会,土木学会耐震工学委 員会, pp.291-294, 1993.

14) Mendoza, C. and Hartzell, S.H.: Slip distribution of the 19 September Michoacan, Mexico earthquake: nearsource and teleseismic constraints, Bull. Seism. Soc. Am., 79, pp.655-669, 1989.

15) Takeo, M. and Kanamori, H. : Simulation of long-period ground motions for the 1923 Kanto earthquakes $(M=8)$, Bull. Earthq. Res. Inst. . Univ. Tokyo, 67, pp.389-436, 1992.

16) Somerville, P.G.: Engineering applications of strong motion simulation, Tectonophysics, 218, pp.195-219, 1993.

17) Takeo, M. and Kanamori, H. : Simulation of the longperiod ground motion near a large earthquake, Bull. Seism.Soc. Am., Vol.87, pp.140-156, 1997.

18) Somerville, P.G., Sen, M. and Chee, B. : Simulation of strong motions recorded during the 1985 Michoacan,
Mexico and Valparaiso, Chili earthquakes, Bull. Seism. Soc. Am., Vol. 81, pp.1-27, 1991.

19) Abrahamson, N.A., Somerville, P.G. and Cornell, C.A.: Uncertainty in numerical strong motion predictions, Proc. Fourth U.S. Nat. Conf. Earthq. Eng., Palm Springs, CA, 1, pp.407-416, 1990.

20) Youngs, R.R., Chiou, S.J., Silva, W.J. and Humphrey, J.R.: Strong ground motion attenuation relationships for subduction zone earthquakes, Seismological Research Letters, 68, pp.58-73, 1997.

21) Crouse, C.B.: Ground motion attenuation equations for earthquakes on the Cascadia Subduction Zone: Earthquake Spectra, V.7, pp.201-236, and p.506, 1991.

22) Matu'ura, M., Iwasaki, T., Suzuki, Y. and Sato, R. : Statical and dynamical study on faulting mechanism of the 1923 Kanto earthquake, J. Phys. Earth, Vol.28, pp.119-143, 1980.

(1997.3.21 受付)

\title{
ESTIMATION OF BROADBAND STRONG GROUND MOTIONS CONSIDERING UNCERTAINTY OF FAULT PARAMETERS
}

\author{
Hisanori OTSUKA, Paul G. SOMERVILLE and Toshiaki SATO
}

\begin{abstract}
Broadband strong ground motion time histories at a site above the fault plane for the 1923 Great Kanto Earthquake and future earthquakes on the Sagami trough are generated, using a hybrid method that computes the ground motions separately in the short period and long period ranges and then combines them into a single time history. Considering uncertainty in the source parameters of future large earthquakes, 960 strong motion time histories are generated. The ground motions at the site are characterized by a smooth median response spectrum and its standard error estimate, together with a subset of ten time histories whose average response spectrum, and whose variability approximately matches the standard error of the smoothed response spectrum.
\end{abstract}

